This is a self-archived - parallel published version of this article in the publication archive of the University of Vaasa. It might differ from the original.

\title{
Market entry into Africa: Acquisitions and international joint ventures. Studies of foreign firms' market entry strategies, challenges, and performance in Africa
}

Author(s): Oguji, Nnamdi; Owusu, Richard A.

Title: $\quad$ Market entry into Africa: Acquisitions and international joint ventures. Studies of foreign firms' market entry strategies, challenges, and performance in Africa

Year: $\quad 2020$

Version: Accepted manuscript

Copyright (C) Wiley. This is the peer reviewed version of the following article: Oguji, N. \& Owusu, R. A. (2020). Market entry into Africa: Acquisitions and international joint ventures. Studies of foreign firms' market entry strategies, challenges, and performance in Africa. Thunderbird International Business Review 63(1), 5-9, which has been published in final form at https://doi.org/10.1002/tie.22170. This article may be used for non-commercial purposes in accordance with Wiley Terms and Conditions for Use of Self-Archived Versions.

\section{Please cite the original version:}

Oguji, N. \& Owusu, R. A. (2020). Market entry into Africa: Acquisitions and international joint ventures. Studies of foreign firms' market entry strategies, challenges, and performance in Africa. Thunderbird International Business Review 63(1), 5-9. https://doi.org/10.1002/tie.22170 


\title{
Market Entry into Africa: Acquisitions and International Joint Ventures. Studies of foreign firms' market entry strategies, challenges, and performance in Africa.
}

\author{
Nnamdi Oguji ${ }^{1}$ Richard A. Owusu ${ }^{2}$
}

****Dr. Nnamdi Oguji

Ph.D. Econ \& Bus Adm. International Business and Marketing

Business Development Expert, KONE Corporation

University of Vaasa

Department of Marketing

P.O. Box 700. FI-65101 Vaasa FINLAND

Email: nnamdi.oguji@gmail.com

Nnamdi Oguji obtained a bachelor's degree in Physics from Federal University of Technology Owerri, Nigeria. Thereafter, Nnamdi obtained a master's degree in Business and Technology from Tampere University of Technology, Finland and a second master's degree in Logistics and Information Service Management from Aalto University, Finland. Nnamdi obtained his Ph.D. in 2015 from the University of Vaasa, Finland and his research interests are in supply chain management, FDI, internationalization, African business, digitalization, and business analytics. Currently, Nnamdi works as a Business Development Expert for KONE Industrial Limited, Finland and is presently affiliated with the University of Vaasa, Finland.

Dr. Richard Afriyie Owusu (Associate Professor)

Linnaeus University, School of Business and Economics, Pedalstråket 11, 392 31, KALMAR, SWEDEN.

Email: richard.owusu@1nu.se :Phone: +46 725949687

Dr. Richard Owusu obtained a bachelor's degree in Political Science and Philosophy from the University of Ghana, Legon. Thereafter, he obtained bachelor's, master's. and Ph.D. degrees in Economics, Management, and International Marketing from Hanken School of Economics, Finland. Dr. Owusu has over 25 scientific publications spanning international market entry strategies; acquisitions and joint ventures; international project business; business networks; and business in Africa. He previously taught at Hanken School of Economics and the University of Vaasa in Finland. He has had further international experience in Australia and the USA. He has participated in several corporate projects such as Globalization of Finnish SMEs; Brands, Innovation and Globalization of Finnish Companies (BIG); and AVANS in Sweden. Currently, Dr. Owusu is an Associate Professor at the School of Business and Economics, Linnaeus University, Sweden. 


\section{ABSTRACT}

While the interest in investing in Africa is rising, the know-how of business on the continent is very limited. There have been only recently few special issues focusing on sub-Saharan Africa in the top international business journals: "Sub-Saharan Africa at a key inflection point" (Thunderbird International Business Review 2009); "Contemporary developments in the management of human resources in Africa" (Journal of World Business 2011); "Contemporary challenges and opportunities of doing business in Africa" (Journal of Technological Forecasting and Social Change 2016); "Critical perspectives on international business in Africa (Critical Perspectives on International Business 2016); "Strategic Management in Africa (Global Strategy Journal, 2017); and "The internationalization of African firms (Thunderbird International Business Review 2016). The aim of this special issue is to advance understanding of international business in Africa and specifically focus on how foreign firms enter African markets via acquisitions and international joint ventures and extend knowledge of these market entry strategies and performance in Africa for research and for foreign firms intending to, or currently doing business in Africa. This guest editorial provides a summary of the five articles and one book review in this special issue categorized into three broad thematic issues: International joint ventures and acquisitions as market entry strategies in Africa; cross-border investments of African firms; and theoretical underpinnings.

Keywords: Market entry strategies into Africa; Acquisitions in Africa; International joint ventures in Africa; Performance of acquisitions and joint ventures in Africa. 


\section{INTRODUCTION}

For the past 40 years, international business (IB) studies have focused on explaining the internationalization of multinational enterprises (MNEs) and the globalization of markets. Yet, studies focused on Africa have thus far been limited. Although interest in investing in Africa is increasing, even as five African economies were the world's five fastest growing economies in the world in 2019 (IMF 2019), the know-how of business on the continent is still very limited for both practitioners and researchers.

Theoretically, contextualized explanations improve theorizing in international business studies (Meyer \& Peng 2005; Welch, Piekkari, Plakoyiannaki \& Paavilainen-Möntymäki 2011). As similar contextualization has been done in transition economies of Central and Eastern Europe (Meyer \& Peng 2005), China (Child \& Tse 2001), and studies on strategies of emerging market MNEs (Cuervo-Cazurra 2012), we believe African markets provide a unique context to test IB theories empirically and develop context-specific theories (Van de Ven \& Jing 2011). The aim of this special issue is to improve IB theories with contextualized studies by addressing two important entry mode choices for foreign firms seeking market entry into Africa: "the choice of international acquisitions and international joint ventures and the performance of these strategies in Africa" 


\section{International joint ventures and acquisitions as market entry strategies in Africa}

International acquisitions and joint ventures are gaining importance in Africa (Boateng and Glaister 2003; Dadzie \& Owusu 2015) partly due to an increasing consolidation of several industries and economic liberation policies implemented by many Africa countries (UNCTAD 2015). While cross-border acquisition may be the ideal strategy for foreign firms entering Africa, the relative institutional difference between African countries and home countries of foreign firms may make full acquisition entry strategies more challenging. For example, as most African economies rely on natural resources as their primary source of economic revenue, some governments impose several local content legislations to protect indigenous firms (Vaaland, Soneye \& Owusu 2012). Local content legislation may hamper feasibility of several Mergers and acquisitions (M\&A) deals, and thus, make it more viable for international joint ventures or other forms of acquisition entry strategies (partial and staged acquisitions).

The total value of acquisitions into Africa within the decade 2005-2014 doubled to \$79bn USD compared to \$34bn USD in the previous decade (1995-2004) (UNCTAD 2015). This trend will continue to rise as BRICS corporations (Brazil, Russia, India, China, and South Africa) and other foreign corporations continue to invest in Africa for the continent's natural resources, vast untapped agricultural sector, and increasing consumer base (Davies \& Segain 2014; UNCTAD 2017). 
A recent literature review showed that most studied acquisitions in Africa were acquisitions in the banking sector motivated to comply with government regulatory reform to meet minimum capitalization set by the respective central banks (Kimberly, Bruce, Taco, \& Leon 2015). Furthermore, there is an increasing trend towards regional M\&A activity in Africa, for example, in the cement industry, aimed at exploiting economies of scale in sourcing, transportation, and distribution and to deter external competitors (UNCTAD 2019). Irrespective of this positive trend, there is limited research on cross-border acquisitions into Africa.

Extant studies on cross-border acquisitions explore how organizations select potential acquisition targets, due diligence process, negotiation of acquisition deals, acquisition entry strategies, acquisition integration, acquisition performance and subsidiary exit. To the best of our knowledge, empirical studies focused on cross-border M\&As in Africa are sparse. The existing studies have mainly been done in the context of Ghana and have focused specifically on the choice between greenfields and acquisitions (Dadzie \& Owusu 2015; Dadzie, Owusu, Amoako, \& Aklamanu 2017), performance of acquisitions and greenfield investments in Ghana (Dadzie, Larimo \& Nguyen 2014) and recently a study addressing how host country capability, target specific experience, institutions, and host country market structure impact Finnish firms' choice for partial, staged and full acquisitions in Egypt, Morocco, Kenya, and South Africa (Oguji \& Owusu 2017). This study showed that various firm-related and institutional factors affect the acquisition decisions of Finnish firms and that there has been a change of the emphases between partial and full acquisitions over time. All of the above studies are, however, limited in the sense of their empirical research being limited to Ghana, and to Finnish companies. The under-representation of Africa in acquisition research and scholarly journals and the growing cross-border M\&As into 
Africa (UNCTAD 2017) suggests the need for more studies that explore various aspects of crossborder acquisitions in the context of Africa.

International joint venture (IJV) is a popular entry strategy through which foreign firms gain market entry into Africa (Boateng 2004). It is an entry strategy where two or more legally separate bodies (one a foreign entity) form a separate jointly-owned entity in which they invest and engage in various decision-making activities (Geringer \& Hebert 1989; Geringer \& Hebert 1991). A review of the literature on IJVs suggests that extant studies focus on: motives of IJV formation; partner selection process; how IJVs are formed; trust and commitment in IJVs; ownership and control mechanisms in IJVs; knowledge transfer in IJVs; IJV stability and performance (Vaidya 2009). Studies on IJVs in Africa are limited. Existing studies have been done on the motives of IJV formation (Bartels, Johnson \& Ahmed 2002; Boateng \& Glaister 2003); ownership and control mechanisms in IJVs (Bartels et al. 2002; Hearn 2015); how IJVs are formed (Gómez-Miranda, Pérez-López, Argente-Linares \& Rodríguez-Ariza 2015); and performance of IJVs in Africa (Boateng \& Glaister 2002).

Thus far, the general conclusion from these studies is that IJVs in Africa often have different characteristics from IJVs in developed economies and require a different framework to look at the various stages IJVs go through. Besides, Africa is a continent with varying degrees of institutional and cultural differences between countries on the continent. The variation in institutional quality across the African continent should lead to varying degrees of ownership mechanisms and roles of IJV board members (Hearn 2015). 
We summarize the articles in the special issue within these thematic areas in the following sections. The first article - "IJVs research on Africa: A systematic literature review, propositions, and contextualization"- Oguji, Degbey \& Owusu, performed a systematic literature review of international joint ventures (IJVs) research in Africa up to 2017 using the 6W procedure and 5Cs quality criteria. A total of 22 relevant studies were found relating to IJV formation, control, ownership, governance, knowledge transfer, IJV motives, strategies and performance. However, limited studies were found on trust, conflict, partner selection, and human resource management in IJVs in Africa. The literature review exposed the lack of Africa's business researchers' interest in these areas as only about one-third of the lead authors were affiliated with African universities. The study showed at a contextual level that institutions is one of the most important factors influencing IJV strategy and success in Africa. Consequently, the authors proposed a greater use of institutional theory in studying IJV themes in Africa.

The next article, "Chinese Cross-Border Mergers \& Acquisitions in the Developing World: Is Africa Unique?" Gunessee and Shuang investigated the uniqueness of Chinese cross-border mergers and acquisitions in Africa compared to other emerging markets. Specifically, they studied five locational determinants of Chinese CBMAs between 2007 and 2016 in developing countries, namely: market size, resource rents, patents, labor productivity, and institutions, and examined whether there are differential effects of these five locational determinants on African countries compared to other developing counterparts. They found a positive hypothesized 'distinctive' effect in Africa compared to other developing countries for only market-seeking and resource-seeking motives. However, with respect to African markets, Chinese acquisitions are relatively more drawn to Africa for natural resource-seeking than market-seeking. According to the authors, this is 
reflected in the 'Chinese investment strategy' that is Africa-specific aimed at using mergers and acquisitions as establishment mode over greenfield investment to acquire strategic resources through majority-ownership to exert greater control over acquired natural resources.

The third article "Developing Total Interpretive Structural Modelling (TISM) of Post-Acquisition Performance: A Case of Zain Acquisition by Bharti Airtel in South Africa” Sanjay, Rishabh, Viout, Zafa, and Owusu investigated factors affecting Bharti Airtel's cross-border post-acquisition performance of Zain acquisition deal in Africa. This study utilized TISM to analyze the postacquisition performance and their findings suggest that when acquiring in similar industry (technology relatedness), prior experience of partnerships and absorptive capacity enhances the post-acquisition performance of the firm.

\section{Cross-border Investments of Africa Firms and Theoretical}

\section{Underpinnings'}

An emerging trend in IB literature is on the internationalization of African firms. As latecomers in the global competitive landscape, African firms' internationalization has been put in the spotlight of debate in internationalization strategy, provoking the academic discipline to answer questions such as "Do African firms internationalize differently from other global firms and do their strategies differ when investing in African versus non-African countries? One emerging question that strikes both practitioners and researchers is owing to their latecomer disadvantage and institutional voids, what capabilities do they need to internationalize? Boso, Adeleye, Ibeh and 
Chizema recently edited a special issue to answer these questions and papers published in that issue provided some insights on how African firms internationalize.

In this special issue, in the fourth article, “CEOs' Dispositional Optimism, Host Country's Rule of Law and Foreign Market Equity Mode Choice of Ghanaian SMEs" Adomako, Frimpong, Muhammad, Robert and Rifaqat investigated how psychological attributes of executives of 227 small and medium-sized enterprises (SMEs) in Ghana affect their firms' foreign entry mode decision. Building on behavioral decision-making theory, they showed that Chief Executive Officers' (CEOs') optimism increases the preference for equity entry mode and even more so in countries with strong rule of law.

In the fifth article, 'Understanding cross-border mergers and acquisitions of African firms: The role of dynamic capabilities in enabling competitiveness amidst contextual constraints" Degbey, Eriksson, Rodgers and Oguji conceptually examined the drivers of cross-border mergers and acquisitions (M\&As) of emerging and developing economy firms, theoretically exploring how dynamic capabilities (DCs) are connected to these drivers, and how African emerging multinational enterprises (EMNEs) can pursue M\&As to achieve global competitiveness. The paper showed that the institutional context of African firms vis-à-vis institutional uncertainty; institutional changes; interconnectedness of formal and informal institutions; influx of diverse organizations; and the resource drivers of the firms can intertwine to provide dynamic capability (sensing, seizing, and transforming) needed to enhance African EMNEs' cross-border M\&A competitiveness. Thus, viewing heterogeneities and institutional changes as opportunities can aid the building up of managerial capabilities needed to drive African EMNEs' competitiveness. 
The last article in this special issue by Esho and White is a review of a new book on looking "back" to the "future" of Business in Africa. It explains what we can learn from the history of business and entrepreneurship in Africa and how historic events are still shaping performance and competitiveness of business enterprises in Africa.

\section{Conclusion and Directions for future research}

The systematic literature review that set the tone for the articles in this special issue found only 22 relevant articles over several decades on IJVs in Africa. Previous systematic literature reviews on entry modes in Africa are very few and they similarly found relatively small numbers of relevant scientific publications in good peer-reviewed journals (see e.g. Kimberly et al. 2015). The studies in this special issue add important new knowledge and insightful implications to the research and practices of market entry to Africa, particularly acquisitions and IJVs. In addition to the studies in this special issue, extant studies and previous special issues mentioned in this editorial contribute insights and frameworks. However, the foregoing studies and their implications touch on only a few areas of business in Africa including even acquisitions and IJVs, and more research is needed within the two modes and business in Africa in general. There is an urgent need to generate greater in-depth knowledge on the contextual differences and challenges posed by the 52 African countries and 45 sub-Saharan. Oguji et al. found that the majority of the 22 studies on IJVs were done on JVs in just three countries: Ghana, Morocco, and Nigeria. Therefore, we propose the use of more qualitative, quantitative, and mixed method research to highlight the nuanced African context well enough, and the contexts of individual African countries and the complex institutional and cultural similarities and differences of Africa and its component countries. 
Researchers should go "the extra mile" to do empirical research. In the study by Oguji et al., several articles were not included because they were conceptual and did not add any new implications based on the "facts on the ground". It is evident that secondary data/statistics are difficult to find and trust, and surveys are sometimes difficult to administer in more than one African country due to resource constraints, language differences, and sometimes bureaucratic hurdles regarding permissions for data collection. These difficulties are gradually eroding with the vast expansion of university education in African countries. Therefore, empirical research should be done wherever possible.

While the nationality of researchers is not important, increased research by Africa-based scholars will be evidence of the improvement of scholarship and research in the large number of new universities across Africa. Research with, and by, Africa-based scholars is likely to reduce the difficulties of access to data, respondents, and informants. The findings of Oguji et al. showed areas that are least studied and suggested institutional theory as a promising framework. Likewise, the other studies provided their suggestions for further research. Finally, Degbey et al. suggested a dynamic capabilities as framework for studying African EMNEs. The readers of this special issue are encouraged to take these studies further and contribute to a) expanding the knowledge of acquisitions, IJVs, and market entry in Africa, and b) international business theories with the benefit of the contextual African research. 


\section{References}

Babarinde O. A. (2009). Africa is open for business: A continent on the move. Thunderbird International Business Review, 51:4, 319-328

Bartels, F. L., Johnson, J. P., \& Ahmed, Z. U. (2002). International Equity Joint Ventures in Ghana and Cote D'Ivoire. Journal of African Business, 3:3, 5-30

Boateng, A. (2004). Determinants of capital structure. International Journal of Social Economics, 31:1/2, $56-66$

Boateng, A. \& Glaister, K. W. (2003). Strategic motives for international joint venture formation in Ghana. Management International Review, 43:2, 107-128

Boateng A. \& Glaister, K. W. (2002). Performance of international joint ventures: evidence for West Africa. International Business Review, 11, 523-541

Boso, N., Adeleye, I., Ibeh, K. \& Chizema, A. (2019). The internationalization of African firms: Opportunities, challenges, and risks. Thunderbird International Business Review, 61:1, 5-12

Child, J. \& Tse, D. K. (2001). China's transition and its implications for international business. Journal of International Business Studies, 32:1; 5-21

Cuervo-Cazurra A. (2012). Extending theory by analyzing developing country multinational companies: solving the goldilocks debate. Global Strategy Journal, 2, 153-167

Dadzie, S. Larimo, J. \& Nguyen, H-L. (2014). Foreign Subsidiary Performance: Evidence from Ghana. Journal of Transnational Management, 19:2, 165-187

Dadzie A. \& Owusu, R. (2015). Understanding Establishment Mode Strategies of Foreign Manufacturing Firms in Ghana. International Journal of Emerging Markets, 10:3, 896-920

Dadzie, S.A., Owusu, R.A., Amoako, K., Aklamanu, A. (2017). Do strategic motives affect ownership mode of Foreign Direct Investments (FDIs) in emerging African markets? evidence from Ghana. Thunderbird International Business Review, Article in Press.

Davies, G. \& Segain, H. (2014). M\&A in Africa: A Regional Overview: Market intelligence, Area: Mergers \& Acquisitions, Jurisdiction: Africa.

https://gettingthedealthrough.com/intelligence/13/article/2022/mergers-acquisitions-africa-regionaloverview. Accessed 1.11.2015

Kimberly M. E., Bruce T. L, Taco H. R. \& Leon F. (2015). Mergers and Acquisitions in Africa: A Review and an Emerging Research Agenda. Africa Journal of Management, 1:2, 137-171 
Geringer, M. J., \& Hebert, L. (1989). Control and performance of international joint ventures. Journal of International Business Studies, Summer, 235-253

Geringer, J. M., \& Hebert, L. (1991). Measuring performance of international joint ventures. Journal of International Business Studies, 22:2, 249-263.

Gómez-Miranda, M. E., Pérez-López, M. C. Argente-Linares, E. \& Rodríguez-Ariza, L. (2015). The impact of organizational culture on competitiveness, effectiveness, and efficiency in SpanishMoroccan international joint ventures. Personnel Review, 44:3, 364 - 387

Hearn, B. (2015). Institutional influences on board composition of international joint venture firms listing on emerging stock exchanges: Evidence from Africa. Journal of World Business, 50:1, 205219

IMF (2019). World Economic and Financial Surveys: Regional Economic Outlook. Sub-Sahara Africa. Recovery amid elevated uncertainty. https://www.imf.org/en/Publications/REO/SSA/Issues/2019/04/01/sreo0419 Accessed 10.05.2020

La Porta, R., Lopez-de-Silanes, F., \& Shleifer, A. (2008). The economic consequences of legal origins. Journal of Economic Literature, 46, 285-332

Meyer, K. E. \& Peng, M. W. (2005). Probing theoretically into Central and Eastern Europe: Transaction, Resources, and Institutions. Journal of International Business Studies. 36:6, 600-621

Oguji, N. \& Owusu, R. (2017). Acquisitions Entry Strategies in Africa: The Role of Institutions, Target-Specific Experience, and Host-Country Capabilities-The Case Acquisitions of Finnish Multinationals in Africa. Thunderbird International Business Review, 59:2, 209-225

Peters, S. (2011). Emerging Africa: The New Frontier for Global Trade Economics, Management, and Financial Markets, 6:1, 44-56

Roberts, J., Kayande, U., \& Srivastava, R. K. (2015). What is Different About Emerging Markets, and What Does It Mean for Theory and Practice Customer Need and Solutions, 2:4, 245-250

Sim, A. B. \& Ali Y. (1998). Performance of International Joint Ventures from Developing and Developed Countries: An Empirical Study in a Developing Country Context. Journal of World Business, 33:4, 357-377

Teagarden, M. B. (2009). Sub-Saharan Africa at a key inflection point. Thunderbird International Business Review, 51:4, 317-318

Transparency International. (2013). Corruption perceptions index http://www.transparency.org/ Accessed 15.09.15 
UNCTAD. (2015). World Investment Report 2015. Value of cross-border M\&A sales, by sector/industry,1990-2014.

http://unctad.org/en/pages/PublicationWebflyer.aspx?publicationid=1245 Accessed 10.5.2020

UNCTAD. (2017). World Investment Report 2017. Investing in the digital economy. http://unctad.org/en/pages/PublicationWebflyer.aspx?publicationid=1782 Accessed 10.5.2020

UNCTAD (2019). Economic development in Africa. made in Africa rules of origin for enhanced intra-African trade.

https://unctad.org/en/PublicationChapters/edar2019_en_ch3.pdf Accessed 10.5.2020

Vaidya, S. (2009). International joint ventures: an integrated framework. Competitiveness Review: An International Business Journal, 19:1, 8-16

Van de Ven, A. H., \& Jing, R. (2011). Indigenous management research in China from an engaged scholarship perspective. Management and Organization Review, 8:1, 123-137

Welch, C., Piekkari, R., Plakoyiannaki, E., \& Paavilainen-Möntymäki, E. (2011). Theorizing from case studies: Towards a pluralist future for international business research. Journal of International Business Studies, 42:5, 740-762

World Bank (2017). Global Economic Prospects.

https://openknowledge.worldbank.org/bitstream/handle/10986/26800/9781464810244.pdf Accessed

10.5.2020 